\title{
Consequences of Mesobuthus tamulus gangeticus (Pocock, 1900) envenomation in albino mice
}

Chaubey MK (1)

(1) Department of Zoology, Mahatma Gandhi College, Gorakhpur, Uttar Pradesh, India.

\begin{abstract}
The present study aimed to investigate the effects of Mesobuthus tamulus gangeticus Pocock (Buthidae) venom on albino mice (NIH strain). Whole venom was obtained by electrical stimulation and its toxicity was determined in albino mice by subcutaneous envenomation. The venom $\mathrm{LD}_{50}$ was $2.5 \mathrm{mg} \mathrm{kg}^{-1}$ of mouse body weight. Toxic effects on different biochemical and enzymatic parameters in blood serum and other tissues of albino mice were determined after experimental envenomation with sublethal doses of $M$. tamulus gangeticus venom. Increased levels of glucose, uric acid and cholesterol, as well as decreased serum total proteins, were observed at 2 and 4 hours after the envenomation. In the liver and muscles, glycogen content dropped after venom injection. Moreover, $M$. tamulus gangeticus venom elevated the enzymatic activity of acid phosphatase (ACP), lactic dehydrogenase (LDH) and alanine aminotransferase (ALT) in the serum of albino mice. In conclusion, M. tamulus gangeticus can be considered a lethal scorpion species.
\end{abstract}

Key words: Mesobuthus tamulus gangeticus, scorpion venom, hyperglycemia, serum enzymes.

\section{INTRODUCTION}

Scorpion sting is a serious health problem of poor communities in tropical and subtropical countries. Of the 1,500 scorpion speciesdistributed all over the world, 50 are lethal to humans (1). The family Buthidae includes the most toxic genera such as Androctonus, Mesobuthus, Centruroides, Leiurus and Tityus. In India, 99 species belonging to all six scorpion genera have been reported, of which 45 are members of the family Buthidae, the largest scorpion family, including most toxic scorpion species (2-6). The clinical symptoms of scorpion sting vary according to the scorpion species and age, the venom composition and the victim's physiological response to the venom. Scorpion sting causes a wide range of conditions from severe local skin reactions to neurological, respiratory and cardiovascular collapse. Scorpion venom is a rich source of various polypeptides which act mainly by affecting specific functions of target channels (7). Buthoid venom causes severe consequences for a wide variety of vertebrate and invertebrate organisms and its toxicity has been attributed to the presence of a large variety of basic polypeptides having three to four disulfide bridges (8).

Scorpion venoms cause initial transient hypertension followed by hypotension (6). Symptoms like severe pain, inflammation, hypersalivation, dysphagia and restlessness appear within a few minutes after the sting and reach maximum severity within five hours, persisting for 24 to 72 hours. The victim's death usually occurs by anaphylaxis, bronchoconstriction, pharyngeal secretion, diaphragmatic paralysis and respiratory 
failure. Most scorpion sting symptoms are due to release of catecholamines from the adrenal glands and release of acetylcholine from postganglionic parasympathetic neurons. Adrenergic symptoms occur with low venom doses, whereas cholinergic symptoms occur with high venom doses, and this duality is the result of the difference in the sensitivity to these neurotransmitters among different organ systems (9). The venom of some red scorpions of the Buthoid family causes acute myocarditis, transient hypertension followed by hypotension, intravascular coagulation, acute pancreatitis, pulmonary edema, increased levels of catecholamines, angiotensin II, glucagon and cortisol, as well as decreased thyroxine and insulin secretion $(3,6,10-15)$. Due to their heterogeneous nature, scorpion venoms show variable reactions in the victim. However, the closer the phylogenic relationship among scorpions, the more similar the symptoms and the immunological properties of their venoms. Furthermore, the various venom constituents may act directly or indirectly and individually or synergistically to exert their effects.

In the present investigation, the effect of venom from the red scorpion Mesobuthus tamulus gangeticus Pocock on biochemical and enzymatic parameters in blood serum and different tissues of albino mice after experimental envenomation was studied.

\section{MATERIALS AND METHODS}

\section{Isolation of M. tamulus gangeticus Venom}

Living scorpions $M$. tamulus gangeticus were purchased from Eastern Scientific Emporium, Gorakhpur, UP, India. Their venom was obtained by electric stimulation of the telson, dissolved in phosphate buffer $(50 \mathrm{mM}, \mathrm{pH}$ 7.2) and centrifuged $\left(\mathrm{MPO1}^{\oplus}\right.$, Tarson Co., India) at 3,000 $\mathrm{x} g, 4^{\circ} \mathrm{C}$, for five minutes. The supernatant was collected, lyophilized and stored at $-4^{\circ} \mathrm{C}$ until use. The venom protein content was determined by the method of Lowry et al. (16).

\section{Toxicity Determination}

The toxicity of $M$. tamulus gangeticus venom was determined in male albino mice (NIH strain) weighing $25 \pm 5 \mathrm{~g}$ by the method of Chaubey and Upadhyay (17). $\mathrm{LD}_{50}$ was determined by subcutaneously injecting $0.1 \mathrm{~mL}$ of different scorpion venom dilutions $(1.5,2.0,2.5,3.0 \mathrm{mg} /$ $\mathrm{kg}$ body weight). For each dose group, four mice were used.

\section{Experimental Protocol for Biochemical Assays}

Three sets of albino mice weighing $25 \pm 5$ mg were used to study the effect of scorpion venom. The first set consisted of 12 albino mice injected with $40 \%$ of 24 -hour $\mathrm{LD}_{50}(1.0 \mathrm{mg} / \mathrm{kg}$ body weight) and the second set also consisted of twelve albino mice injected with $80 \%$ of 24 hour $\mathrm{LD}_{50}(2.0 \mathrm{mg} / \mathrm{kg}$ body weight $)$ of scorpion venom subcutaneously. Mice of the first two sets were divided into two groups: Group I and Group II, including six animals each. Group I and Group II mice from the first and second sets were used at 2 and 4 hours after envenomation, respectively, for biochemical analysis. The third set consisted of six mice serving as control that received only phosphate buffer $(50 \mathrm{mM}, \mathrm{pH}$ 7.2). The estimation of biomolecules and the determination of enzymatic activities were done separately, using the same experimental protocols already described.

\section{Determination of Serum Biochemical and Enzymatic Parameters}

The effects of $M$. tamulus gangeticus venom on serum glucose, uric acid, cholesterol, total protein, acid phosphatase, lactic dehydrogenase and alanine aminotransferase were determined in albino mice. At the end of each experimental period, mice were anesthetized using vapors of ether. Blood was then collected by cardiac puncture and allowed to clot; clear serum was isolated for further analysis.

\section{Glucose determination}

Serum glucose level was determined according to the method of Mendel et al. (18) and expressed as milligram/100 $\mathrm{mL}$ of serum.

\section{Uric acid determination}

Serum uric acid level was determined by the method of Folin (19) and expressed as milligram $/ 100 \mathrm{~mL}$ of serum.

\section{Cholesterol determination}

Serum cholesterol level was determined by the method of Abell et al. (20) and expressed as milligram $/ 100 \mathrm{~mL}$ of serum. 


\section{Total protein determination}

Total serum protein level was determined by the method of Lowry et al. (16) and expressed as milligram/100 mL of serum.

\section{Determination of acid phosphatase (ACP) activity}

ACP activity in blood serum was determined by the method of Bergmayer (21) and expressed as micromoles of formed p-nitrophenol/30 minutes $\mathrm{x}$ milligram of protein.

\section{Determination of lactic dehydrogenase (LDH) activity}

LDH activity in blood serum was determined by the method of Annon (22) and expressed as micromoles of reduced pyruvate/45 minutes $\mathrm{x}$ milligram of protein.

\section{Determination of alanine aminotransferase (ALT) activity}

ALT activity in blood serum was determined by the method of Reitman and Frankel (23) and expressed as units of ALT activity/hour $\mathrm{x}$ milligram of protein.

\section{Determination of glycogen content}

Glycogen content in liver and muscle tissues was determined in albino mice after $M$. tamulus gangeticus envenomation. Thus, anesthetized mice previously envenomated according to the experimental protocol were sacrificed for the collection of liver and muscle tissues, which were kept at $-20^{\circ} \mathrm{C}$ until analysis. The glycogen level in liver and muscle tissues was determined by the method of Dubois et al. (24) and expressed as gram/100 g of tissue.

\section{Statistical Analysis}

Results were expressed as mean \pm SE of six replicates. Student's t-test was used to verify significant differences relative to controls and between sublethal doses and exposure periods (25). F-test was performed to verify the regression coefficient equality (26).

\section{RESULTS}

\section{Toxicity Determination}

The median lethal dose $\left(\mathrm{LD}_{50}\right)$ of $M$. tamulus gangeticus venom was $2.5 \mathrm{mg} / \mathrm{kg}$ of body weight of albino mice.
Effect of M. tamulus gangeticus Venom on

\section{Serum Metabolite Level}

Glucose level was $147.94 \%$, compared to control, after two hours of treatment with $80 \%$ of 24-hour $\mathrm{LD}_{50}$ of scorpion venom. This level increased to $174.74 \%$ after four hours of the same treatment (Table 1). Uric acid level was $131.44 \%$, compared to the control group, and increased to $149.82 \%$ after four hours of treatment with $80 \%$ of 24-hour $\mathrm{LD}_{50}$ of scorpion venom (Table 1). After two hours of treatment with $80 \%$ of 24 -hour $\mathrm{LD}_{50}$ of scorpion venom, serum cholesterol level was $130.62 \%$, compared to control. This level peaked (157.42\%) after four hours of treatment with $80 \%$ of 24-hour $\mathrm{LD}_{50}$ of scorpion venom (Table 1 ). A maximum decrease in total protein level $(61.20 \%)$ was found after four hours of treatment with $80 \%$ of 24 -hour $\mathrm{LD}_{50}$ of scorpion venom (Table 1). All these changes in different biochemical parameters were time- and dose-dependent (Table $1, p<0.05$, Student's t-test, F-test).

\section{Effect of M. tamulus gangeticus Venom on Glycogen Level}

Glycogen level in the liver tissue of albino mice decreased to $73.13 \%$ and $51.6 \%$ after 2 and 4 hours of treatment with $80 \%$ of 24 -hour $\mathrm{LD}_{50}$ of scorpion venom, respectively (Table 2). Similarly, glycogen level in the muscle tissue of albino mice decreased to $74.23 \%$ and $53.56 \%$ after 2 and 4 hours of treatment with $80 \%$ of 24 -hour $\mathrm{LD}_{50}$ of scorpion venom, respectively (Table 2). The decrease in glycogen level in the liver and muscle of albino mice after treatment with scorpion venom was time- and dose-dependent (Table 2, $p<0.05$, Student's t-test, F-test).

\section{Effect of M. tamulus gangeticus Venom on Serum Enzyme Activity}

The increase in serum ACP activity was 123.48 and $139.47 \%$ after 2 and 4 hours of treatment with $80 \%$ of 24 -hour $\mathrm{LD}_{50}$ of scorpion venom, respectively (Table 3 ). The increase in circulating LDH and ALT activity was $133.84 \%$ and $145.56 \%$, respectively, after two hours of treatment with $80 \%$ of 24-hour $\mathrm{LD}_{50}$ of scorpion venom (Table 3). $\mathrm{LDH}$ and ALT activity further increased to $147.83 \%$ and $175.35 \%$, respectively, after four hours of treatment with $80 \%$ of 24 -hour $\mathrm{LD}_{50}$ of scorpion venom (Table 3 ). The increase in the activity of these circulating enzymes was time- and dose-dependent (Table 3, $p<0.05$, Student's t-test, F-test). 
Table 1. Effect of $40 \%$ and $80 \%$ of 24 -hour $\mathrm{LD}_{50}$ of $M$. tamulus gangeticus venom on glucose, uric acid, cholesterol and total protein levels in the blood serum of albino mice

\begin{tabular}{|c|c|c|c|c|c|}
\hline \multirow[b]{2}{*}{ Parameters } & \multirow[b]{2}{*}{ Control } & \multicolumn{2}{|c|}{ After 2 hours } & \multicolumn{2}{|c|}{ After 4 hours } \\
\hline & & $40 \%$ of $24-h L_{50}$ & $80 \%$ of $24-h L_{50}$ & $40 \%$ of $24-h L_{50}$ & $80 \%$ of $24-h L_{50}$ \\
\hline Glucose $^{1}$ & $\begin{array}{c}68.85 \pm 0.93 \\
(100)\end{array}$ & $\begin{array}{c}87.02^{* \#} \pm 0.96 \\
(126.40)\end{array}$ & $\begin{array}{c}101.86^{* \#} \pm 0.84 \\
(147.94)\end{array}$ & $\begin{array}{c}110.04^{* \#} \pm 0.97 \\
(159.83)\end{array}$ & $\begin{array}{c}121.68^{* \#} \pm 0.89 \\
(174.74)\end{array}$ \\
\hline Uric acid ${ }^{1}$ & $\begin{array}{c}2.62 \pm 0.07 \\
(100)\end{array}$ & $\begin{array}{c}2.98^{* \#} \pm 0.09 \\
(113.81)\end{array}$ & $\begin{array}{c}3.44^{* \#} \pm 0.08 \\
(131.44)\end{array}$ & $\begin{array}{c}3.40^{* \#} \pm 0.07 \\
(129.62)\end{array}$ & $\begin{array}{c}3.92^{* \#} \pm 0.09 \\
(149.82)\end{array}$ \\
\hline Cholesterol $^{1}$ & $\begin{array}{c}159.00 \pm 3.68 \\
(100)\end{array}$ & $\begin{array}{c}185.20^{* \#} \pm 2.81 \\
(116.48)\end{array}$ & $\begin{array}{c}207.66^{* \#} \pm 2.42 \\
(130.62)\end{array}$ & $\begin{array}{c}224.59^{* \#} \pm 2.74 \\
(141.25)\end{array}$ & $\begin{array}{c}250.29^{* \#} \pm 2.97 \\
(157.42)\end{array}$ \\
\hline $\begin{array}{c}\text { Total } \\
\text { protein }\end{array}$ & $\begin{array}{c}3.29 \pm 0.08 \\
(100)\end{array}$ & $\begin{array}{c}2.90^{* \#} \pm 0.07 \\
(88.14)\end{array}$ & $\begin{array}{c}2.45^{* \#} \pm 0.05 \\
(74.33)\end{array}$ & $\begin{array}{c}2.41^{* \#} \pm 0.07 \\
(73.08)\end{array}$ & $\begin{array}{c}2.01^{* \#} \pm 0.06 \\
(61.20)\end{array}$ \\
\hline
\end{tabular}

${ }^{1}$ Values represent milligram $/ 100 \mathrm{~mL}$ of blood serum; ${ }^{2}$ values represent gram $/ 100 \mathrm{~mL}$ of blood serum; values in parentheses indicate percent change with respect to control considered 100\%; ${ }^{*}$ significant ( $p<0.05$, Student's t-test); ${ }^{*}$ significant $(p<0.05, \mathrm{~F}$-test).

Table 2. Effect of $40 \%$ and $80 \%$ of $24-$ hour $\mathrm{LD}_{50}$ of $M$. tamulus gangeticus venom on glycogen level in the liver and muscle tissue of albino mice

\begin{tabular}{c|c|c|c|c|c}
\hline \multicolumn{2}{|c|}{} & \multicolumn{2}{|c|}{ After 2 hours } & \multicolumn{2}{c}{ After 4 hours } \\
\hline Tissues & Control & $40 \%$ of $24-\mathrm{h} \mathrm{LD}_{50}$ & $80 \%$ of $24-\mathrm{h} \mathrm{LD}_{50}$ & $40 \%$ of $24-\mathrm{h} \mathrm{LD}_{50}$ & $80 \%$ of $24-\mathrm{h} \mathrm{LD}_{50}$ \\
\hline \multirow{2}{*}{ Liver } & $2.46 \pm 0.07$ & $2.12^{* *} \pm 0.08$ & $1.80^{* *} \pm 0.06$ & $1.64^{* \#} \pm 0.04$ & $1.27^{* *} \pm 0.08$ \\
& $(100)$ & $(86.42)$ & $(73.13)$ & $(66.79)$ & $(51.60)$ \\
\hline \multirow{2}{*}{ Muscle } & $0.93 \pm 0.004$ & $0.81^{* \#} \pm 0.001$ & $0.69^{* *} \pm 0.003$ & $0.63^{* *} \pm 0.002$ & $0.50^{* *} \pm 0.001$ \\
& $(100)$ & $(87.74)$ & $(74.23)$ & $(67.81)$ & $(53.56)$ \\
\hline
\end{tabular}

Values represent gram of glycogen/100 g of tissue; values in parentheses indicate percent change with respect to control considered 100\%; ${ }^{*}$ significant $\left(p<0.05\right.$, Student's t-test); ${ }^{*}$ significant $(p<0.05$, F-test).

Table 3. Effect of $40 \%$ and $80 \%$ of $24-h L_{50}$ of $M$. tamulus gangeticus venom on acid phosphatase (ACP), lactic dehydrogenase (LDH) and alanine aminotransferase (ALT) levels in the blood serum of albino mice

\begin{tabular}{c|c|c|c|c|c}
\hline \multicolumn{2}{|c|}{} & \multicolumn{2}{|c|}{ After 2 hours } & \multicolumn{2}{c}{ After 4 hours } \\
\hline Parameters & Control & $40 \%$ of $24-\mathrm{h} \mathrm{LD}_{50}$ & $80 \%$ of $24-\mathrm{h} \mathrm{LD}_{50}$ & $40 \%$ of $24-\mathrm{h} \mathrm{LD}_{50}$ & $80 \%$ of $24-\mathrm{h} \mathrm{LD}_{50}$ \\
\hline \multirow{2}{*}{ ACP } & $0.694 \pm 0.004$ & $0.766^{* *} \pm 0.005$ & $0.857^{* *} \pm 0.006$ & $0.886^{* *} \pm 0.007$ & $0.968^{* \#} \pm 0.004$ \\
& $(100)$ & $(110.42)$ & $(123.48)$ & $(127.64)$ & $(139.47)$ \\
\hline \multirow{2}{*}{ LDH } & $105.64 \pm 3.04$ & $132.22^{* *} \pm$ & $141.39^{* *} \pm 1.81$ & $140.12^{* *} \pm 1.42$ & $156.17^{* *} \pm 2.01$ \\
& $(100)$ & $(116.64)$ & $(133.84)$ & $(132.64)$ & $(147.83)$ \\
\hline \multirow{2}{*}{ ALT } & $15.98 \pm 0.74$ & $19.73^{* \#} \pm 0.46$ & $23.26^{* *} \pm 0.54$ & $24.96^{* \#} \pm 0.57$ & $28.02^{* *} \pm 0.64$ \\
& $(100)$ & $(123.44)$ & $(145.56)$ & $(156.18)$ & $(175.35)$ \\
\hline
\end{tabular}

ACP: micromoles of formed $p$-nitrophenol/30 minutes $x$ milligram of protein; $L D H:$ micromoles of reduced pyruvate/45 minutes $x$ milligram of protein; ALT: units of alanine aminotransferase activity/hour x milligram of protein; *significant $(p<0.05$, Student's t-test); ${ }^{*}$ significant $(p<0.05$, F-test). 


\section{DISCUSSION}

In the present study, venom from the scorpion $M$. tamulus gangeticus was isolated by electric stimulation and its median lethal dose $\left(\mathrm{LD}_{50}\right)$ was $2.5 \mathrm{mg} / \mathrm{kg}$ body weight of albino mice. The effect of sublethal doses of this scorpion venom on certain biochemical and enzymatic parameters was studied. Serum glucose level increased after $M$. tamulus gangeticus envenomation, resulting in hyperglycemia. This could be due to reduced insulin secretion, excessive release of catecholamines, decreased thyroid hormone levels, and increased cortisol and glucagon levels observed during earlier studies with other scorpion species $(5,14,15,27)$. Reduced insulin and increased glucagon secretion causes a sustained fall in glucose clearance and promotes glycogenolysis and gluconeogenesis, thereby increasing blood glucose levels (28). Serum uric acid level is highly dependent on renal excretion, as well as on endogenous production (29). Plasma volume expansion increases the renal excretion of uric acid by proximal tubular reabsorption and vice versa (30). Increased secretion of glucagon, cortisol and catecholamines along with insulin resistance or reduced insulin level stimulate glycogenolysis in the muscles promote lactate formation (31). Thus, during scorpion envenomation, lactate is produced but not utilized, leading to lactate acidosis which in turn inhibits the secretory mechanism of uric acid, increasing serum uric acid level (31).

Hypercholesterolemia may occur with hypothyroidism, diabetes and acute pancreatitis. The concentration of serum cholesterol is thyroiddependent, with thyroid hormone enhancing both the rate of cholesterol synthesis and the rate of catabolism. In hypothyroidism, cholesterol utilization is lower than cholesterol synthesis. Hypercholesterolemia is also due to decreased insulin secretion. The net result is an increase in cholesterol level. Radha Krishna Murthy and Medh (32) reported increased serum cholesterol levels during $M$. tamulus envenomation, which supports the present results. The liver produces almost all serum proteins except immunoglobulin, and albumin is the major constituent of serum proteins. The decrease in total serum protein level probably indicates decreased synthetic activity of the liver under pathological conditions. Similar results have also been reported with Leiurus quinquestriatus and Palamneus gravimanus envenomation $(33,34)$.

Liver glycogen is largely related to storage and export of hexose units for the maintenance of blood glucose, whereas muscle glycogen acts as a readily available source of hexose units for glycolysis within the muscle itself (35). Increased glucagon, corticosteroid and catecholamine levels during scorpion envenomation function synergistically and stimulate hepatic glucose production $(31,36)$. It has also been reported that under stress conditions carbohydrate reserves are depleted to meet the energy demand (37). These changes provide ample stimulus for glycogenolysis in the liver and muscles, which indicates rapid utilization of glycogen in response to stress caused by envenomation. Since glycogen depletion is more prevalent under hypoxia condition, a situation similar to hypoxia may occur in the tissues of envenomed mice (37).

Acid phosphatase (ACP) is a lysosomal enzyme that plays an important role in catabolism, pathological necrosis, autolysis and phagocytosis (38). Liver ischemia and hypoxia increase the activity of lysosomal enzymes, which may be the cause of tissue necrosis in cardiac and liver tissues under hypoxia condition, resulting in an increased serum level of these enzymes (39).

Elevated activity of lactic dehydrogenase (LDH) and alanine aminotransferase (ALT) in the blood serum was observed, indicating myocardial and liver damage after $M$. tamulus gangeticus venom administration. The main causes of altered permeability of myocardial and liver cells are circulatory hypoxia, metabolic disorders and inflammation (40). Gajalakshmi (41) reported a significant rise in serum GPT levels during Buthus tamulus envenomation. Similarly, Radha Krishna Murthy et al. (42) reported an increase in circulating LDH and ALT levels during scorpion venom administration. The venom of almost all lethal scorpion species exerts similar pathological abnormalities in experimental animals $(33,43)$.

\section{COPYRIGHT}

(C) CEVAP 2010

\section{SUBMISSION STATUS}

Received: March 10, 2010.

Accepted: April 19, 2010.

Abstract published online: June 7, 2010.

Full paper published online: August 31, 2010. 


\section{CONFLICTS OF INTEREST}

There is no conflict.

\section{FINANCIAL SOURCE}

The author is highly thankful to the University Grants Commission, New Delhi, India, for providing financial assistance.

\section{CORRESPONDENCE TO}

MUKESH KUMAR CHAUBEY, Department of Zoology, Mahatma Gandhi College, Gorakhpur, 273 001, UP, India. Email: chaubey.mukesh@ rediffmail.com.

\section{REFERENCES}

1. Keegan HL. Scorpions of medical importance. Mississippi: University Press of Mississippi; 1980. $140 \mathrm{p}$.

2. Tikeder BK, Bastawade BD. The fauna of India: Scorpions. Scorpionida, Arachnida. Calcutta: Zoological Survey of India; 1983. p. 1-587. 3 vols.

3. Amaral CF, Rezende NA. Both cardiogenic and non-cardiogenic factors are involved in the pathogenesis of pulmonary oedema after scorpion envenoming. Toxicon. 1997;35(7):997-8.

4. Kankonkar RC, Kulkurni DG, Hulikavi CB. Preparation of potent anti-scorpion-venomserum against the venom of red scorpion (Buthus tamulus). J Postgrad Med. 1998;44(4):85-92.

5. Radha Krishna Murthy K, Anita AG. Reduced insulin secretion in acute myocarditis produced by scorpion (Buthus tamulus) venom injection in rabbits. Indian Heart J. 1986;38(6):467-9.

6. Radha Krishna Murthy K, Yeolekar ME. Electrocardiographic changes in acute myocarditis produced by the scorpion (Buthus tamulus) venom. Indian Heart J. 1986;38(1):20610.

7. Gordon D, Maskowitz H, Eitan M, Warner C, Catterall WA, Zlotkin E. Localization of receptor sites for insect-selective toxins on sodium channels by site-directed antibodies. Biochemistry. 1992;31(33):7622-8.

8. Rochat H, Bernard P, Couraud F. Scorpion toxins: chemistry and mode of action. Adv Cytopharmacol. 1979;3(1):325-34

9. Freire-Maia L, Pinto GI, Franco I. Mechanism of the cardiovascular effects produced by purified scorpion toxin in the rat. J Pharmacol Exp Ther. 1974;188(1):207-13.

10. Radha Krishna Murthy K, Zolphaghrian H, Medh JD, Kudalkar JA, Yeolekar ME, Pandit SP, et al. Disseminated intravascular coagulation and disturbances in carbohydrate and fat metabolism in acute myocarditis produced by scorpion
(Buthus tamulus) venom. Indian J Med Red. 1988;87(1):318-25.

11. Radha Krishna Murthy K, Medh JD, Dave BN, Vakil YE, Billimoria FR. Acute pancreatitis and reduction of $\mathrm{H}^{+}$ion concentration in gastric secretions in experimental acute myocarditis produced by Indian red scorpion, Buthus tamulus venom. Indian J Exp Biol. 1989;27(3):242-4.

12. Radha Krishna Murthy K, Shenoi R, Vaidyanathan P, Kelkar K, Sharma N, Rao S, et al. Insulin reverses haemodynamic changes and pulmonary oedema in children stung by Indian red scorpion Mesobuthus tamulus concanesis, Pocock envenoming. Ann Trop Med Parasitol. 1991;85(1):651-7.

13. Radha Krishna Murthy K, Vakil AE. Elevation of angiotensin levels in dogs by Indian red scorpion (Buthus tamulus) venom and its reversal by administration of insulin and tolazoline. Indian J Med Res. 1988;88(1):376-9.

14. Radha Krishna Murthy K, Haghnazari L. The blood level of glucagon, cortisol and insulin following the injection of venom by the scorpion (Mesobuthus tamulus, Pocock) in dogs. J Venom Anim Toxins. 1999;5(1):47-55.

15. Radha Krishna Murthy K, Zare A. Effect of Indian red scorpion (Mesobuthus tamulus concanesis, Pocock) venom on thyroxine and triiodothyronine in experimental acute myocarditis and its reversible by species specific antivenom. Indian J Exp Biol. 1998;36(1):16-21.

16. Lowry OH, Rosenbrough NJ, Farr AL, Randall RJ. Protein measurement with phenol reagent. J Biol Chem. 1951;193(1):265-75.

17. Chaubey MK, Upadhyay RK. Biochemical and enzymatic changes after black scorpion Heterometrus fastigiousus, Couzijn envenomation in experimental albino mice. J Appl Toxicol. 2008;28(7):874-84.

18. Mendel B, Kemp A, Myers DK. A colorimetric micro-method for determination of glucose. Biochem J. 1954;56(4):639-46.

19. Folin O.Standardized methodsfor the determination of uric acid in unlaked blood and in urine. J Biol Chem. 1933;101(1):111-25.

20. Abell LL, Levy BB, Brodie BB, Kendall FE. A simplified method for the estimation of total cholesterol in serum and demonstration of its specificity. J Biol Chem. 1952;195(1):357-66.

21. Bergmayer UH. Methods of enzymatic analysis. New York: Academic Press; 1967. 1129 p.

22. Annon TM.Sigma diagnostic: lactate dehydrogenase (quantitative, colorimetric determination in serum, urine and cerebrospinal fluid) at 400-500 nm. Procedure. 1985;500.

23. Reitman S, Frankel S. A colorimetric method for the determination of serum glutamic oxalacetic 
and glutamic pyruvic transaminases. Am J Clin Pathol. 1957;28(1):56-63.

24. Dubois M, Gilles KA, Hamilton JK, Rebers PA, Smith F. Colorimetric method for the determination of sugars and related substances. Anal Chem. 1956;28(3):350-6.

25. Armitage P, Berry G, Matthews JNS. Statistical methods in medical research. 4th ed. Oxford: Blackwell Science; 2002.817 p.

26. Sokal RR, Rohlf FJ. Introduction to biostatistics. San Francisco: W H Freeman and Co.; 1973. 368 p.

27. Amaral CF, Dias MB, Campolina D, Proietti FA, de Rezende NA. Children with adrenergic manifestation of envenomation after Tityus serrulatus scorpion sting are protected from early anaphylactic antivenom reactions. Toxicon. 1994;32(2):211-5.

28. Sonksen PH, West TET. Carbohydrate and diabetes mellitus. Rec Adv Endocrinol Metabol. 1978;1(1):160-87.

29. Leyva F, Wingrove CS, Godsland IF, Stevenson JC. The glycolytic pathway to coronary heart disease: a hypothesis. Metabolism. 1998;47(6):657-62.

30. Steele TN. Importance and pathogenesis of diuretic-induced hyperuricemia. In: Puschett JB, Greenberg A, editors. Diuretics IV: chemistry, pharmacology and clinical applications. Amsterdam: Elsevier Science; 1993. 231-8 p.

31. Radha Krishna Murthy K. The scorpion envenoming syndrome: a different perspective. The physiological basis of role of insulin in scorpion envenoming. J Venom Anim Toxins. 2000;6(1):4-51.

32. Radha Krishna Murthy K, Medh JD. Increase in serum free fatty acids, phospholipids and reduction in total cholesterol in acute myocarditis produced by scorpion (Buthus tamulus) venom injection in dogs. Indian Heart J. 1986;38(5):36972.

33. More SS, Kiran KM, Gadag JR. Dose dependent serum biochemical alterations in wistar albino rats after Palamneus gravimanus (Indian black scorpion) envenomation. J Basic Clin Physiol Pharmacol. 2004;15(3-4):263-75.

34. Omran MA, Abel-Rahman MS. Effect of the scorpion Leiurus quinquestriatus (H\&E) venom on the clinical chemistry parameters of the rat. Toxicol Lett. 1992;61(1):99-109.

35. RennieMJ,Edwards RHT.Carbohydratemetabolism of skeletal muscle and its disorders. In: Randle PJ, Steiner DF, Whelan WJ, editors. Carbohydrate metabolism and its disorders. England: Academic London; 1981. p. 1-118. 3 vols.

36. Douglas WW. Polypeptides: angiotensin, plasma kinins and others. In: Gilman AG, Goodman LS, Rall TW, Murad F, editors. The pharmacological basis of therapeutics. New York: Macmillan Publishing Company; 1985. p. 663-76.

37. Dezwann A, Zandee DI. The utilization of glycogen and accumulation of some intermediate during anaerobiosis in Mytilus edulis L. Comp Biochem Physiol. 1972;43(1):47-52.

38. Abou-Donia MB. Increased acid phosphatase activity in hens following an oral dose of leptophos. Toxicol Lett. 1978;2(4):199-203.

39. Fredlund PE, Ockerman PA, Vang JO. Acidosis and increased plasma levels of beta-Dglucosidase and beta-D-galactosidase after hepatic inflow occlusion in the pig. Acta Chir Scand. 1974;140(3):234-41.

40. Willerson JT, Scales F, Mukherjee A, Platt MR, Templeton GH, Fink GS, et al. Abnormal myocardial fluid retention as an early manifestation of ischemic injury. Am J Pathol. 1977;87(1):159-88.

41. Gajalakshmi BS, Ramaswamy N, Thiagarajan C, Yahya GM. Certain observations in electrocardiogram and enzyme variation in dogs following scorpion venom injection. Indian J Physiol Pharmacol. 1978;22(4):397-400.

42. Radha Krishna Murthy K, Abbas Zare M, Haghnazari L. The use of serotherapy to reverse ECG and cardiac enzyme changes caused by scorpion Mesobuthus tamulus concanesis, Pocock envenoming. J Venom Anim Toxins. 1999;5(2):154-71.

43. de Rezende NA, Dias MB, Campolina D, ChavezOlortegui C, Diniz CR, Amaral CF. Efficacy of antivenom therapy for neutralizing venom antigens in patients stung by Tityus serrulatus scorpion. Am J Trop Med Hyg. 1995;52(3):27780. 